ISSN 2073-4344

www.mdpi.com/journal/catalysts

Article

\title{
Biomimetic Catalysts for Oxidation of Veratryl Alcohol, a Lignin Model Compound
}

\author{
Gustavo González-Riopedre, María Isabel Fernández-García *, Esther Gómez-Fórneas and \\ Marcelino Maneiro * \\ Department of Inorganic Chemistry, Faculty of Sciences, University of Santiago de Compostela, Lugo \\ 27002, Spain
}

* Author to whom correspondence should be addressed; E-Mail: marcelino.maneiro@usc.es;

Tel.: +34-982-824-106; Fax: +34-982-285-872.

Received: 21 December 2012; in revised form: 8 February 2013 / Accepted: 17 February 2013 / Published: 4 March 2013

\begin{abstract}
Kraft pulp has to be bleached to eliminate the chromophoric structures, which cause a darkening of the pulp. In Nature, an equivalent role is assumed by ligninolytic enzymes such as lignin peroxidases, manganese peroxidases and laccases. The development of low molecular weight manganese peroxidase mimics may achieve environmentally-safe bleaching catalysts for the industry. Herein we report the synthesis and characterization of six manganese(III) complexes 1-6, incorporating dianionic hexadentate Schiff base ligands $\left(\mathrm{H}_{2} \mathrm{~L}^{1}-\mathrm{H}_{2} \mathrm{~L}^{4}\right)$ and different anions. Complex 4, $\mathrm{Mn}_{2} \mathrm{~L}_{2}^{2}\left(\mathrm{H}_{2} \mathrm{O}\right)_{2}(\mathrm{DCA})_{2}$ was crystallographically characterized. Complexes $\mathbf{1}-\mathbf{4}$ behave as more efficient mimics of peroxidase in contrast to 5-6. We have studied the use of these complexes as catalysts for the degradation of the lignin model compound veratryl alcohol. The biomimetic catalysts were used in conjunction with chlorine-free inexpensive co-oxidants as dioxygen or hydrogen peroxide. Yields up to $30 \%$ of veratryl alcohol conversion to veratraldehyde have been achieved at room temperature in presence of air flow using $0.5 \%$ of catalyst.
\end{abstract}

Keywords: manganese; peroxidases; lignin; schiff bases; veratryl alcohol 


\section{Introduction}

The predominant chemical pulping process used nowadays is the Kraft process, which, at high temperatures and under forceful alkaline conditions, is able to remove large amounts of lignin from the cellulose fiber by reductive depolymerisation with sulfide [1]. The formation of various chromophoric structures giving rise to absorption of visible light cannot be avoided in the Kraft process and will cause a darkening of the pulp [2].

The objective of pulping and bleaching of wood is the selective removal of lignin without degrading the polysaccharides, and the removal of colored structures, which are originally present in the wood pulp or have been formed during the pulping process. Since toxic chlorinated compounds have been detected in the waste water streams of mills that use molecular chlorine as bleaching agent, the paper and pulp industry has been sought to design alternative bleaching sequences which use other oxidizing agents [3]. So far, several different bleaching processes have been developed using dioxygen, hydrogen peroxide and ozone as proposed oxidants [4].

A singular approach in this field is to mimic biological systems [5]. Enzymes called lignin peroxidases, manganese peroxidases and laccases are able to catalyze such lignin degradation [6]. Synthetic models for manganese peroxidase have been developed [7] from polydentate ligands [8,9] or porphyrins $[10,11]$.

In our search of biomimetic models for peroxidase, we have also reported active manganese complexes involving tetradentate ONNO Schiff bases, and the influence of the geometry around the manganese ion on peroxidase activity has also been studied by us [12-14].

The dimeric nature of the complexes is decisive on their peroxidase activity [15]. Dimeric complexes can be achieved using the appropriate ligands, for instance polydentate Schiff bases with both inner and outer compartments.

Herein we report six $\mathrm{Mn}$ (III) complexes obtained from the reaction between different manganese salts and the Schiff base ligands (see Figure 1): $N, N^{\prime}$-bis(3-methoxy-5-bromo-salicylidene) propane-1,2-diamine $\quad\left(\mathrm{H}_{2} \mathrm{~L}^{1}\right) ; \quad N, N^{\prime}$-bis(3-methoxysalicylidene)ethylenediamine $\quad\left(\mathrm{H}_{2} \mathrm{~L}^{2}\right) ; \quad N, N^{\prime}$-bis (3-methoxy-5-bromo-salicylidene)propane-1,3-diamine $\left(\mathrm{H}_{2} \mathrm{~L}^{3}\right)$ and $N, N^{\prime}$-bis(3-methoxysalicylidene)2,2'-dimethylpropane-1,3-diamine $\left(\mathrm{H}_{2} \mathrm{~L}^{4}\right)$.

Figure 1. Structure of the Schiff base ligands $\mathrm{H}_{2} \mathrm{~L}^{1}-\mathrm{H}_{2} \mathrm{~L}^{4}$.

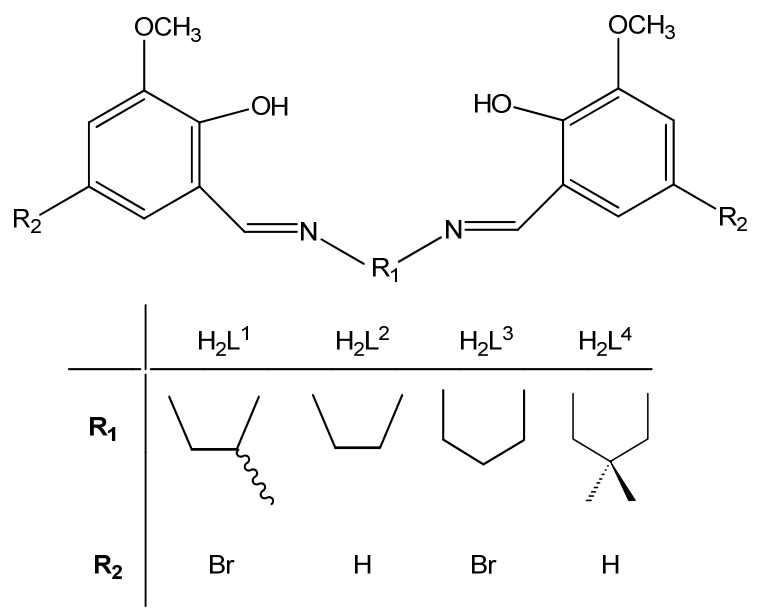


We have also tried to take advantage of the ability of the anions perchlorate (in the case of Complexes 1 and 5), AcAc (acetylacetonate, in the case of 2) and DCA (diacyanamide, in the case of 4) and nitrate (in the case of $\mathbf{3}$ and 6) for establishing hydrogen bonds that would lead to new supramolecular architectures.

Peroxidase-like activity of the complexes was followed by the oxidation of the diammonium salt of 2,2'-azinobis(3-ethylbenzothiazoline)-6-sulfonic acid (ABTS) at $\mathrm{pH} 6.8$ in aqueous solution. The possibility of evaluating catalyst properties of 1-6 for pulp-bleaching purposes has been studied using veratryl alcohol (VA), which can be considered as a model compound for lignin substructures [16].

\section{Results and Discussion}

\subsection{Synthesis and Characterization of the Complexes}

Complexes 1-6 were prepared in high yield as detailed in Section 3.3. Elemental analyses establish the formula $\mathrm{MnL}^{1}\left(\mathrm{H}_{2} \mathrm{O}\right)_{2}\left(\mathrm{ClO}_{4}\right)$ for $\mathbf{1}, \mathrm{MnL}^{1}\left(\mathrm{H}_{2} \mathrm{O}\right)_{2}(\mathrm{AcAc})$ for 2, $\mathrm{MnL}^{2}\left(\mathrm{H}_{2} \mathrm{O}\right)_{2}\left(\mathrm{NO}_{3}\right)\left(\mathrm{CH}_{3} \mathrm{OH}\right)$ for 3, $\mathrm{MnL}^{2}\left(\mathrm{H}_{2} \mathrm{O}\right)(\mathrm{DCA})$ for 4, $\mathrm{MnL}^{3}\left(\mathrm{H}_{2} \mathrm{O}\right)_{2}\left(\mathrm{ClO}_{4}\right)$ for 5, and $\mathrm{MnL}^{4}\left(\mathrm{H}_{2} \mathrm{O}\right)_{2}\left(\mathrm{NO}_{3}\right)\left(\mathrm{H}_{2} \mathrm{O}\right)_{3}$ for 6. Molar conductivity measurements in $10^{-3} \mathrm{M}$ dimethylformamide solutions, in the range 68-115 $\mu \mathrm{S}$, show the electrolyte behavior for $\mathbf{1}, \mathbf{3}, \mathbf{5}$ and $\mathbf{6}$, while $\mathbf{2}$ and $\mathbf{4}$ show non-electrolyte behavior.

ESI (electrospray-ionization) mass spectra registered in methanol show peaks corresponding to the fragment $[\mathrm{MnL}]^{+}$for all the complexes, indicating the coordination of the Schiff base ligand to the metal centre. Other minor signals could be assigned to $\left[\mathrm{Mn}_{2} \mathrm{~L}_{2}(\mathrm{X})\right]^{+}$units (being $\mathrm{X}$ the anion), which could be attributed to the presence of dimeric species.

Values for the magnetic moments at room temperature are very close to the spin-only value of 4.9 B.M., as expected for a high-spin magnetically diluted $\mathrm{d}^{4}$ manganese(III) ion.

Infrared spectroscopy (IR) verifies the coordination of the Schiff base ligand to the manganese ion, since in all cases we observe a negative shift $\left(4-10 \mathrm{~cm}^{-1}\right)$ of the $v\left(\mathrm{CN}_{\text {imine }}\right)$ band and also a positive shift $\left(10-30 \mathrm{~cm}^{-1}\right)$ of the $v\left(\mathrm{CO}_{\text {phenol }}\right)$ mode with respect to the free ligand. These data suggest the coordination of the Schiff base in its dianionic form through the inner phenol oxygen and the imine nitrogen atoms. Some other IR spectroscopical features allow understanding how the former manganese salt anions are bound to the central ion or even indicating their coordination behavior:

a. The broad unsplit band at $1120 \mathrm{~cm}^{-1}$ in $\mathbf{1}$ and $\mathbf{5}$ is indicative of the presence of the uncoordinated perchlorate anion [12], its characteristic $v_{4}$ stretching mode at ca. $635 \mathrm{~cm}^{-1}$ can also easily be identified;

b. Two new bands at 1546 and $1438 \mathrm{~cm}^{-1}$ in 2 are assigned to the symmetric and asymmetric acetylacetonate bidentate modes suggesting its coordination to the manganese ion [17];

c. The appearance of a new strong and sharp band at $1384 \mathrm{~cm}^{-1}$, together with bands at ca. 740 and $850 \mathrm{~cm}^{-1}$ are characteristic of the non-coordinated nitrate counterion in complexes 3 and $\mathbf{6}$ [18];

d. Two new bands at 2148 and $2266 \mathrm{~cm}^{-1}$ in 4 are assigned to the symmetric and asymmetric diacyanamide modes [19]. 


\subsection{Crystal Structure of 4}

Single crystals of Complex 4, suitable for X-ray diffraction studies, were obtained by slow evaporation of the methanolic solution at room temperature. Intensity data were collected on a Bruker X8 APEXII difractometer employing graphite-monochromated $M o-K \alpha$ radiation $(\lambda=0.71073 \AA)$ at $100 \mathrm{~K}$.

The geometry around the manganese ion can be described as distorted octahedral. Main bond distances and angles are collected in Table 1. An ORTEP view of 4 with the atomic numbering scheme is shown in Figure 2.

Figure 2. ORTEP view of the environment around the manganese ion in 4 (left) and mercury drawing of the resulting $\mu$-aquo dimer (right).
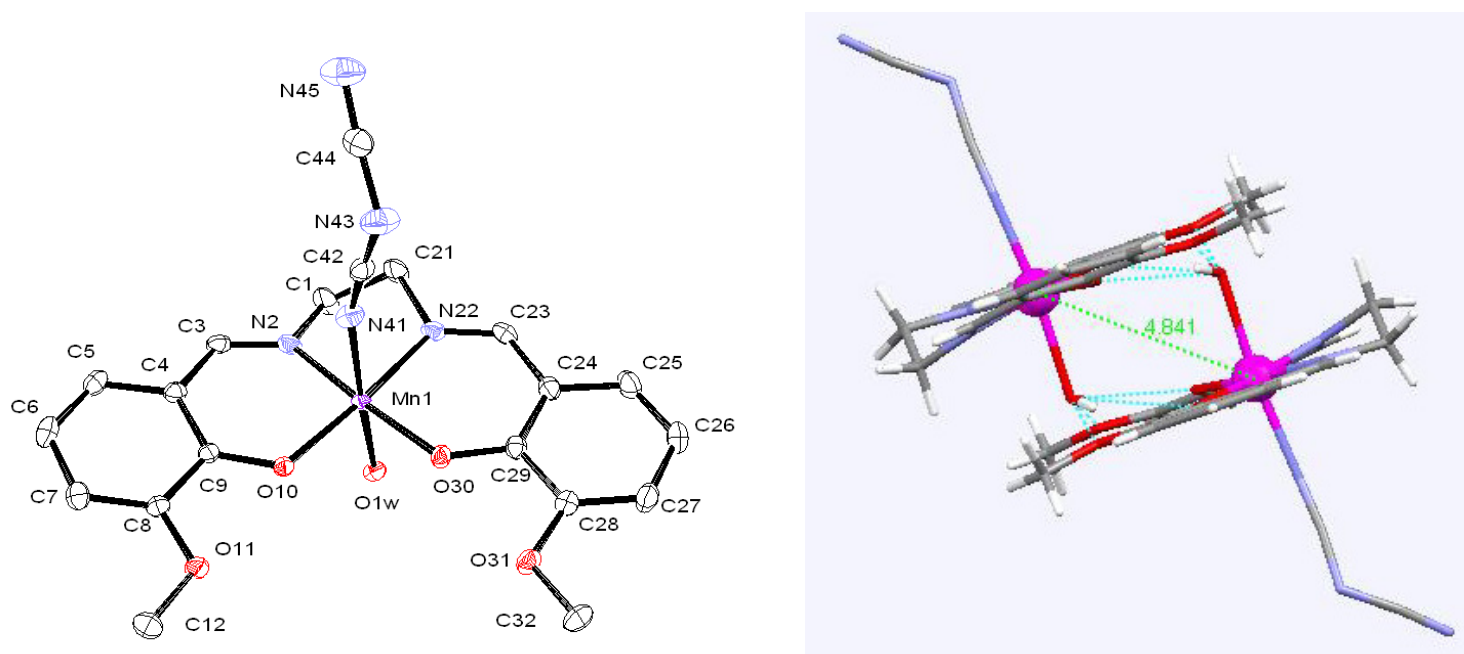

The coordination sphere around each manganese center comprises the planar Schiff base ligand, tightly bound to the metal ion through the inner $\mathrm{N}_{2} \mathrm{O}_{2}$ compartment by the $\mathrm{N}_{\text {imine }}$ and $\mathrm{O}_{\text {phenol }}$ atoms ( $\mathrm{Mn}-\mathrm{N}_{\text {imine }}$ bond lengths of $1.98-1.99 \AA$ and $\mathrm{Mn}-\mathrm{O}_{\text {phenol }}$ of $1.88 \AA$ which are typical of such complexes and corroborate the bisdeprotonation of the ligands), occupying the equatorial positions and giving rise to two six-membered chelate rings (which are nearly planar) and an additional five-membered chelate ring.

Table 1. Selected bond lengths $(\AA)$ and angles $\left(^{\circ}\right)$ for Complex 4.

\begin{tabular}{cccc}
\hline Mn1-O10 & $\mathbf{1 . 8 8 5}(\mathbf{1 5})$ & Mn1-O30 & $\mathbf{1 . 8 8 1 ( 1 5 )}$ \\
\hline Mn1-N2 & $1.981(18)$ & Mn1-N22 & $1.990(19)$ \\
Mn1-N41 & $2.255(2)$ & Mn1-O1w & $2.303(16)$ \\
& & & \\
O10-Mn1-O30 & $93.78(6)$ & N2-Mn1-N22 & $82.52(8)$ \\
N41-Mn1-O1w & $174.32(7)$ & O10-Mn1-N41 & $94.00(7)$ \\
O10-Mn1-O1w & $90.66(7)$ & O30-Mn1-O1w & $90.11(6)$ \\
\hline
\end{tabular}


The axial positions of the octahedron are occupied by a capping water molecule and a dicyanamide molecule. The Jahn-Teller elongation expected for $\mathrm{d}^{4}$ high-spin manganese(III) appears outstanding in the axis orthogonal to the plane of the Schiff base ligand, with distances ranging from 2.26 to $2.30 \AA$, considerably longer than the equatorial $\mathrm{Mn}-\mathrm{O}$ bond lengths quoted earlier [12-15].

The superstructure of $\mathbf{4}$ involves associations via a combination of $\pi$-aryl offset interactions [20] and hydrogen bonds between capping water molecules and both phenoxy and methoxy oxygen atoms of the neighboring Schiff base ligand, forming $\mu$-aquo dimeric units. These hydrogen bonds are charge-assisted, that is, the hydrogen bond donor and/or acceptor carry positive and negative ionic charges, respectively, and hence are rather strong and short. As result of these supramolecular interactions, the $\mathrm{Mn} \cdots \mathrm{Mn}$ distances of about $4.84 \AA$ are short for monomeric compounds.

\subsection{Electrochemical Studies}

The electrochemical behavior of complexes 1, 3, $\mathbf{4}$ and $\mathbf{5}$ has been studied. Cyclic voltammograms of the complexes exhibit a quasi-reversible one-electron reduction-oxidation wave, which at slow scan rates of about $0.02 \mathrm{~V} \mathrm{~s}^{-1}$ is reversible (Figure 3, Table 2).

The shape of the cyclic voltammograms for all the complexes is quite similar, with a peak-to-peak separation from 0.080 to 0.108 . The rate of reversibility of these compounds suggests that they could act as catalysts in different processes. The redox potentials of 1, 4 and 5 appear in the same range, the values of $\mathbf{5}$ being slightly more positive. The reduction wave of $\mathbf{3}$ is observed at more negative potentials $\left(E_{\mathrm{red}}=-0.237 \mathrm{~V}\right)$.

Figure 3. Cyclic voltammogram (versus saturated calomel electrode) for $\mathbf{1}$ at a scan rate of $0.02 \mathrm{~V} \mathrm{~s}^{-1}$.

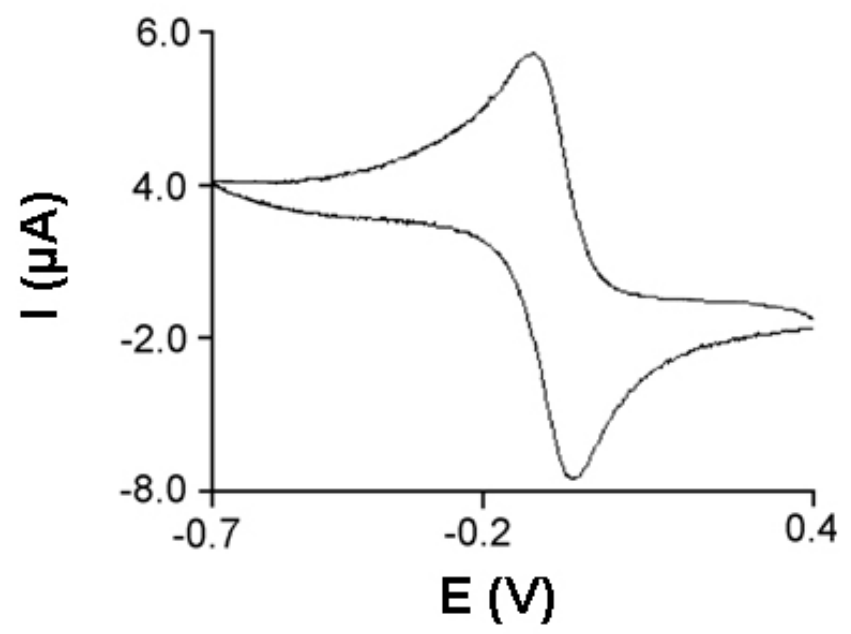

Normal pulse voltammetry can be applied to such systems and provides an additional proof of the oxidation state of the manganese in the former complexes. Anodic and cathodic currents were observed when the initial potentials were more negative than the wage range. However, when the initial potentials were more positive than the wave voltage range, only cathodic currents were observed. These data indicate that in solution only the oxidized forms of the redox systems exist, i.e., manganese(III). 
Table 2. Electrochemical data for the complexes (values in V).

\begin{tabular}{ccccc}
\hline & $\boldsymbol{E}_{\mathbf{0 x}}$ & $\boldsymbol{E}_{\text {red }}$ & $\boldsymbol{E}_{1 / 2}$ & $\Delta \boldsymbol{E}_{\text {(ox-red) }}$ \\
\hline $\mathbf{1}$ & -0.034 & -0.114 & -0.074 & 0.080 \\
$\mathbf{3}$ & -0.154 & -0.237 & -0.196 & 0.083 \\
$\mathbf{4}$ & 0.047 & -0.057 & -0.005 & 0.104 \\
$\mathbf{5}$ & 0.068 & -0.040 & 0.014 & 0.108 \\
\hline
\end{tabular}

\subsection{Peroxidase Studies}

ABTS is colorless and it reacts readily with $\mathrm{H}_{2} \mathrm{O}_{2}$ in the presence of a peroxidase catalyst to yield a stable green colored radical cation $\mathrm{ABTS}^{++}$[21], which presents characteristic absorption bands at 415, 650,735 and $815 \mathrm{~nm}$. The extent of the reaction can be measured quantitatively at $\lambda=650 \mathrm{~nm}$ since $\varepsilon=12000 \mathrm{M}^{-1} \mathrm{~cm}^{-1}$ has been determined. The oxidation potential of ABTS to provide ABTS ${ }^{+}$is invariable over a wide range of $\mathrm{pH}$. In the absence of the complex, a solution of ABTS and $\mathrm{H}_{2} \mathrm{O}_{2}$ is stable for several hours without showing any formation of $\mathrm{ABTS}^{++}$.

The reaction of ABTS with $\mathrm{H}_{2} \mathrm{O}_{2}$ in the presence of 1-4 generates $\mathrm{ABTS}^{++}$and the characteristic absorption bands of this species could be established (Figure 4). The rate of formation of ABTS ${ }^{+}$of about 40-62\% indicates a relevant peroxidase activity by Complexes 1-4. Complexes 5-6 do not show significant peroxidase-like activity since the UV absorbances corresponding to the $\mathrm{ABTS}^{+}$radical cation are negligible in the assays with these complexes.

Figure 4. UV absorption spectra of Complex 4 (straight line) recorded 10 min after injecting $10 \mu \mathrm{L}$ of a $10^{-3}$ methanolic solution of the appropriate complex to $3 \mathrm{~mL}$ aqueous solution in the peroxidases probes. Broken lines are spectra of ABTS $+\mathrm{H}_{2} \mathrm{O}_{2}$ and 2,2'-azinobis(3-ethylbenzothiazoline)-6-sulfonic acid (ABTS) + complex, measured separately.

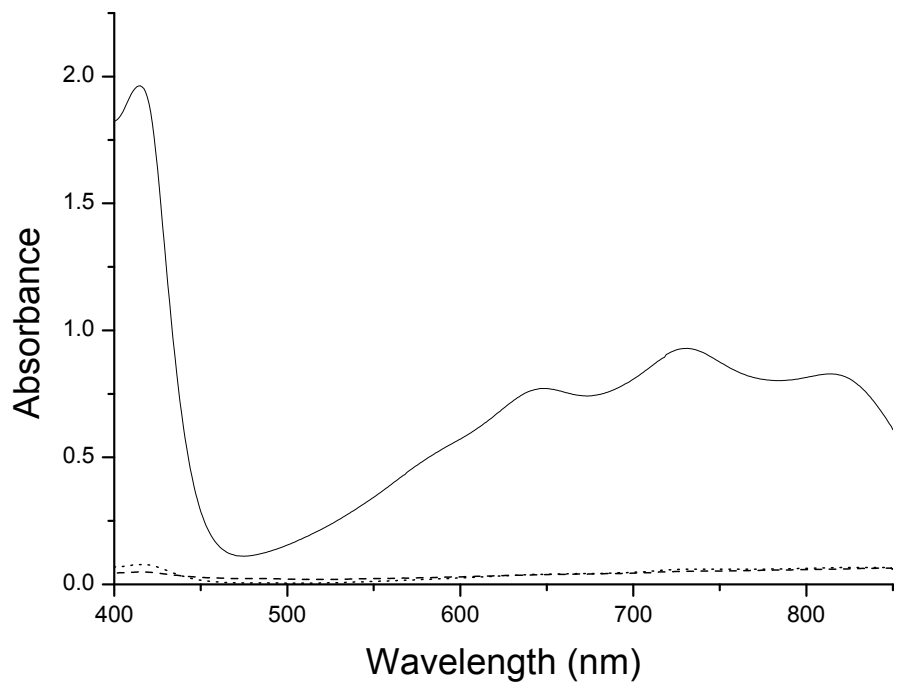

The extent of the conversion of ABTS increases to $70-76 \%$ using a larger amount of the oxidant $(250 \mu \mathrm{L} 10 \mathrm{M})$. However the higher turnovers numbers (TON; calculated as the number of moles of substrate that a mole of catalyst can convert before becoming inactivacted) of catalytic cycles is 
achieved by reducing the concentration of the catalyst in solution (Figure 5). This behavior can be explained by the reaction completion so that more turnovers are observed with lower catalyst load. The percentages of conversions in these conditions range from 53 to $61 \%$.

The exact mechanism of oxidation process is not clear at present. High-valent intermediates such as $\mathrm{Mn}(\mathrm{IV})$ or $\mathrm{Mn}(\mathrm{V})$ have been proposed in different redox processes catalyzed by other synthetic manganese complexes [22-25]. Accordingly, Complexes 1-4 could follow a pathway involving the interconversion between the $\mathrm{Mn}_{2}{ }_{2}$ and $\left[\mathrm{Mn}^{\mathrm{IV}}=\mathrm{O}_{2}\right.$ forms. The resolution of the crystal structure of 4 reveals a short distance between the manganese ions. Both the short intermetallic separation and the occurrence of two labile coordination sites could facilitate the $\mu$-bridging mode of peroxide leading to $\mathrm{O}-\mathrm{O}$ cleavage and formation of the $\left[\mathrm{Mn}^{\mathrm{IV}}=\mathrm{O}\right]_{2}$ form of catalyst.

The way to achieve the dimeric nature of the complexes is decisive on their peroxidase activity since the oxidation of the hydroperoxide ion involves an intramolecular two-electron transfer reaction which is forbidden for a monomeric $\mathrm{Mn}$ (III) complex. In this sense, the self-assembly of the manganese complexes through hydrogen bonding arises as a key issue to enhance the peroxidase activity for this type of complex [13]. The methoxy groups of the outer compartments of the Schiff bases $\mathrm{H}_{2} \mathrm{~L}^{1}-\mathrm{H}_{2} \mathrm{~L}^{4}$ are essential to establish a supramolecular network that approximates the manganese ions to distances below $5 \AA$, which is considerably shorter than the $10 \AA$ for monomeric compounds [26].

Figure 5. Turnovers numbers of catalytic cycles for 1-6 using the standard conditions detailed in Section 3.5 (a); increasing the $\left[\mathrm{H}_{2} \mathrm{O}_{2}\right]$ adding $250 \mu \mathrm{L} 10 \mathrm{M}$ instead of $50 \mu \mathrm{L}$ (b); reducing the [complex] adding $1 \mu \mathrm{L} 10^{-3} \mathrm{M}$ instead of $10 \mu \mathrm{L}$ (c).

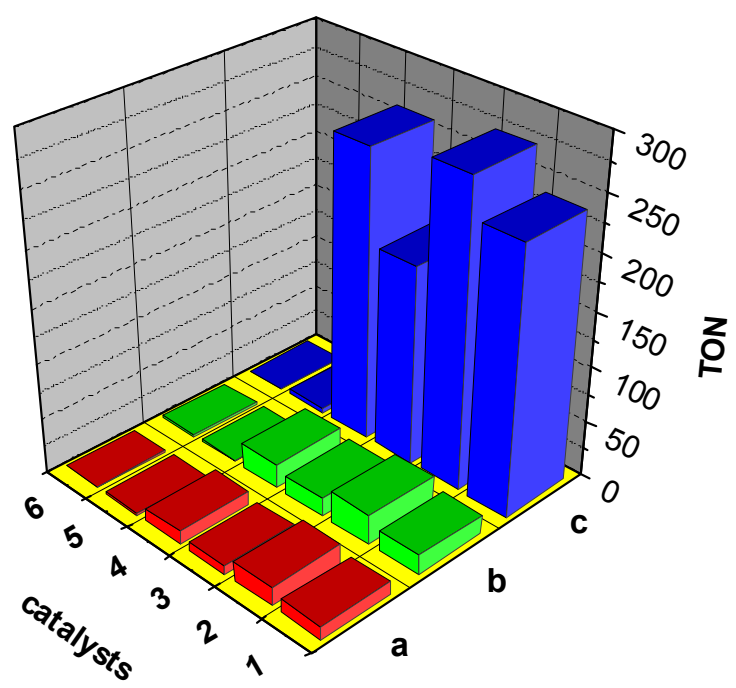

\subsection{Oxidation of the Lignin Analogue Veratryl Alcohol}

Veratryl alcohol (3,4-dimethoxybenzyl alcohol) is a commonly used lignin model [27]. This substrate is optimal for our experiments since Complexes 1-6 have no absorbance at $310 \mathrm{~nm}$, whereas its oxidized product veratraldehyde absorbs strongly at $310 \mathrm{~nm}\left(\varepsilon=9300 \mathrm{M}^{-1} \mathrm{~cm}^{-1}\right)$ [28]. The oxidation studies have been done both in presence and absence of air flow bubbling in order to check for the effect of a saturated atmosphere of molecular oxygen in the process. Dioxygen is an attractive 
choice as a nonpoisonous and inexpensive oxidant for industrial processes. The processes that are based on molecular oxygen can also be considered to be ecologically benign processes, because water and hydrogen peroxide are the main side products derived from the oxidant [29].

Veratraldehyde product were isolated and purified following the procedure described in Section 3.6. ${ }^{1} \mathrm{H}$ nuclear magnetic resonance (NMR) spectroscopy confirms the absence of the methylene proton signal at $4.61 \mathrm{ppm}$ from the original veratryl alcohol as well as the appearance of a new peak at $9.62 \mathrm{ppm}$ corresponding to the aldehyde. A control reaction under the same conditions without catalyst did not give any fraction of veratraldehyde.

The results of the oxidation of veratryl alcohol to veratraldehyde are shown in Figure 6. The activity of the catalysts 1-6 decreases as the length of the alkyl bridge between the coordinating amines increases.

Figure 6. Conversions of veratryl alcohol (VA) to veratraldehyde catalyzed by 1-6: (a) reaction conditions as detailed in Section 3.6 but in absence of air flow; (b) reaction conditions as detailed in Section 3.6 but reducing reaction time to $3 \mathrm{~h}$; (c) reaction conditions as detailed in Section 3.6.

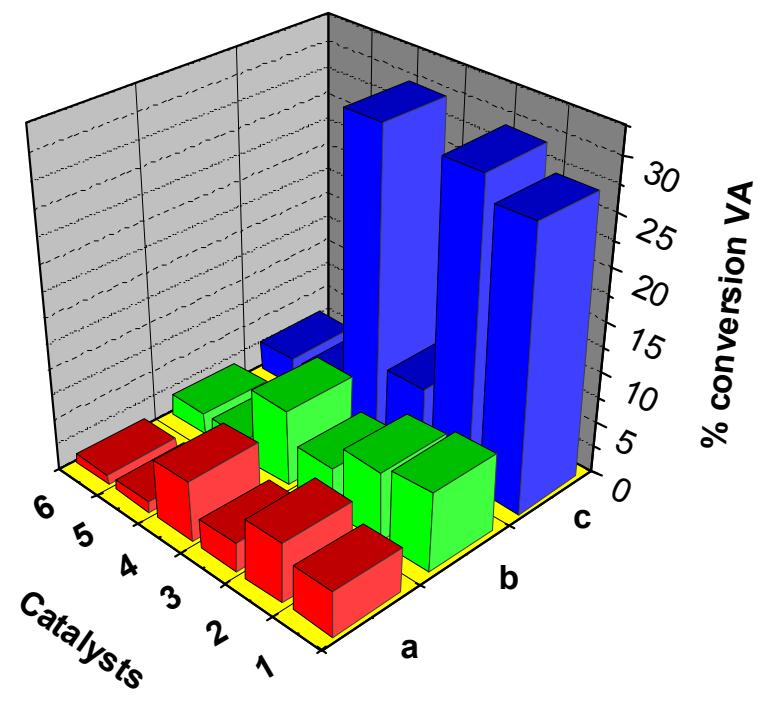

Complexes 1, 2 and 4, behave as better catalysts in this process. An explanation arises from the short two-carbon chain between imine groups in these complexes; the short chain length constricts the chelate ring once nitrogens coordinate to the metal and it leads to a tetragonally elongated octahedral geometry. An axial water molecule in this class of distorted geometries constitutes a quite labile ligand, which would generate a vacant position in the coordination sphere to accommodate the substrate molecule. On the other hand, the flexible three-membered alkyl chain between the imine groups in the Mn compounds 5-6 favors a better stabilization of a high-symmetry octahedral geometry, which subsequently makes the generation of a vacancy difficult. The activity of 3, intermediate between these two groups of complexes, may be derived from its more negative potentials observed in electrochemical studies.

Conversions up to $30 \%$ were obtained at $22{ }^{\circ} \mathrm{C}$ with an air flow bubbling for $10 \mathrm{~h}$, using the Catalyst 4 and three equivalents of $\mathrm{H}_{2} \mathrm{O}_{2}$ respective to the substrate. These are mild conditions 
compared with the experimental setup of other authors [30,31], where high temperatures and pressures are needed to reach similar yields with different catalysts. Moreover, most of the oxygen-activating homogeneous transition-metal catalysts are investigated in organic solvents [32,33]; however, only a few are known to be active in water [34].

No conversion has been shown in absence of catalyst or in absence of hydrogen peroxide. Air flow providing oxygen as oxidant is crucial to increase the yield, but a degradation of about $7 \%$ of veratryl alcohol is observed when the experiment was done without air flow. However, presence of both catalyst and $\mathrm{H}_{2} \mathrm{O}_{2}$ is necessary to find some degradation of veratryl alcohol. This behavior suggests that hydrogen peroxide could induce the oxidation of the catalyst to a more catalytically active species, such as $\left[\mathrm{Mn}^{\mathrm{IV}}=\mathrm{O}\right]_{2}$ dimers, which subsequently would degrade the veratryl alcohol using dioxygen as oxidant.

\section{Experimental Section}

\subsection{Materials}

All the starting materials (Aldrich) and solvents (Probus) used for the synthesis were of commercially available reagent grade and were used without further purification.

\subsection{Physical Measurements}

Elemental analyses were performed on a Carlo Erba Model 1108 CHNS-O elemental analyzer. The IR spectra were recorded as $\mathrm{KBr}$ pellets on a Bio-Rad FTS 135 spectrophotometer in the range of $4000-400 \mathrm{~cm}^{-1}$. ${ }^{1} \mathrm{H}$ NMR spectra were recorded on a Bruker AC-300 spectrometer using $\mathrm{CD}_{3} \mathrm{OD}$ $(296 \mathrm{~K})$ as solvent and $\mathrm{SiMe}_{4}$ as an internal reference. The electro-spray mass spectra of the compounds were obtained on a Hewlett-Packard model LC-MSD 1100 instrument (positive ion mode, 98:2 $\mathrm{CH}_{3} \mathrm{OH}-\mathrm{HCOOH}$ as mobile phase, 30 to $100 \mathrm{~V}$ ). Room-temperature magnetic susceptibilities were measured using a digital measurement system MSB-MKI, calibrated using mercury tetrakis(isothiocyanato)cobaltate(II) $\mathrm{Hg}\left[\mathrm{Co}(\mathrm{NCS})_{4}\right]$ as a susceptibility standard. Conductivities of $10^{-3} \mathrm{M}$ solutions in DMF were measured on a Crison microCM 2200 conductivity meter.

Electrochemical experiments were performed using an EG\&G PAR model 273 potentiostat, controlled by EG\&G PAR model 270 software. A Metrohm model 6.1204.000 graphite disc coupled to a Metrohm model 628-10 rotating electrolyte device was used as a working electrode. A saturated calomel electrode was used as a reference and a platinum wire used as an auxiliary electrode. All measurements were made with ca. $10^{-3} \mathrm{~mol} \mathrm{dm}^{-3}$ solutions of the complexes in dimethylformamide using $0.2 \mathrm{~mol} \mathrm{dm}^{-3} \mathrm{NBu}_{4} \mathrm{PF}_{6}$ as a supporting electrode. Cyclic voltammetry measurements were performed with a static graphite electrode, whilst direct-current and pulse voltammograms were recorded with the graphite disc rotating at 2000 revolutions per minute. 


\subsection{Synthesis of the Complexes}

$\mathbf{M n}_{2} \mathrm{~L}_{2}{ }_{2}\left(\mathrm{H}_{2} \mathbf{O}\right)_{4}\left(\mathbf{C l O}_{4}\right)_{2}$ (1), $1.99 \mathrm{mmol}(1.00 \mathrm{~g})$ of $\mathrm{H}_{2} \mathrm{~L}^{1}$ was dissolved in $100 \mathrm{~mL}$ of a $1: 1$ methanol-ethanol mixture and $1.99 \mathrm{mmol}(0.72 \mathrm{~g})$ of $\mathrm{Mn}\left(\mathrm{ClO}_{4}\right)_{2} \cdot 6 \mathrm{H}_{2} \mathrm{O}$ was added to the initial yellow solution which changed to green (CAUTION: Although no problems were encountered in this work, perchlorates are potentially explosive and should be handled in only small quantities and with care!). After stirring for $10 \mathrm{~min}, 3.98 \mathrm{mmol}(0.16 \mathrm{~g})$ of $\mathrm{NaOH}$, dissolved in a small quantity of water, was added, and the mixture turned dark. The progress of the reaction was followed by thin-layer chromatography (TLC) for three days and the mixture was then filtered. The complex was obtained from the filtrate as a brown solid after crystallization. It was isolated by filtration and washed with diethyl ether and dried in air. Anal. Calcd. for $\mathrm{C}_{38} \mathrm{H}_{44} \mathrm{Br}_{4} \mathrm{Cl}_{2} \mathrm{Mn}_{2} \mathrm{~N}_{4} \mathrm{O}_{16}$ (1312.4): C, 34.7; H, 3.4; N, 4.3. Found: C, 34.0; H, 3.4; N, $4.0 \%$. MS ES $(\mathrm{m} / z): 553\left[\mathrm{MnL}^{+}\right.$. IR $\left(\mathrm{KBr}, \mathrm{cm}^{-1}\right): v(\mathrm{O}-\mathrm{H}) 3438(\mathrm{~m})$, $v(\mathrm{C}=\mathrm{N}) 1625$ (vs), $v(\mathrm{C}-\mathrm{O}) 1295(\mathrm{~s}), v_{3}\left(\mathrm{ClO}_{4}{ }^{-}\right) 1120$ (vs). $\mu=4.7$ BM. Conductivity (in DMF) $\Lambda_{M}=82 \mu \mathrm{S}$.

$\mathbf{M n}_{2} \mathbf{L}_{2}{ }_{2}\left(\mathbf{H}_{2} \mathbf{O}\right)_{4}(\mathbf{A c A c})_{2}(\mathbf{2}), \mathrm{H}_{2} \mathrm{~L}^{1}(1.4 \mathrm{mmol}, 0.70 \mathrm{~g})$ was dissolved in methanol (40 $\left.\mathrm{mL}\right)$ and $\mathrm{Mn}(\mathrm{AcAc})_{3} \cdot 4 \mathrm{H}_{2} \mathrm{O}(1.4 \mathrm{mmol}, 0.40 \mathrm{~g})$, dissolved in methanol was added to the initial yellow solution, which changed to green. After stirring for $10 \mathrm{~min}, \mathrm{NaOH}(2.8 \mathrm{mmol}, 0.11 \mathrm{~g})$, dissolved in a small quantity of water, was added and the mixture turned black. The reaction mixture was refluxed for 2 hours, and then concentrated in vacuo to half its volume. The complex was obtained as black crystals, which were isolated by filtration, washed with diethyl ether and dried in air. Anal. Calcd. for $\mathrm{C}_{48} \mathrm{H}_{58} \mathrm{Mn}_{2} \mathrm{Br}_{4} \mathrm{~N}_{4} \mathrm{O}_{16}$ (1375.8): C, 41.8; H, 4.2; N, 4.1. Found: C, 40.4; H, 3.9; N, 4.3 \%. MS ES (m/z): $553\left[\mathrm{MnL}^{+}\right.$. IR $\left(\mathrm{KBr}, \mathrm{cm}^{-1}\right): v(\mathrm{O}-\mathrm{H}) 3432(\mathrm{~m}), v(\mathrm{C}=\mathrm{N}) 1626(\mathrm{vs}), v(\mathrm{C}-\mathrm{O}) 1298(\mathrm{~s}), v_{\text {asym }}\left(\mathrm{CO}_{2}\right) 1546$ (s), $v_{\mathrm{sym}}\left(\mathrm{CO}_{2}\right) 1438(\mathrm{~m}) . \mu=5.0 \mathrm{BM}$. Conductivity (in DMF) $\Lambda_{M}=10 \mu \mathrm{S}$.

$\mathbf{M n}_{2} \mathrm{~L}^{2}{ }_{2}\left(\mathbf{H}_{2} \mathbf{O}\right)_{4}\left(\mathbf{N O}_{3}\right)_{2}\left(\mathbf{C H}_{3} \mathbf{O H}\right)_{2}$ (3). $1.00 \mathrm{mmol}(0.33 \mathrm{~g})$ of $\mathrm{H}_{2} \mathrm{~L}^{2}$ was dissolved in methanol (50 $\left.\mathrm{mL}\right)$ and $1.00 \mathrm{mmol}(0.26 \mathrm{~g})$ of $\mathrm{Mn}\left(\mathrm{NO}_{3}\right)_{2} \cdot 4 \mathrm{H}_{2} \mathrm{O}$ was added to the initial yellow solution which changed to brown. After $3 \mathrm{~h}$ of stirring at room temperature slow evaporation of solvent lead to deposition of a brown compound. The product was collected by filtration, washed with diethyl ether and then dried in vacuo. Anal. Calcd. for $\mathrm{C}_{38} \mathrm{H}_{52} \mathrm{Mn}_{2} \mathrm{~N}_{6} \mathrm{O}_{20}$ (511.4): C, 44.6; H, 5.1; N, 8.2. Found: C, 44.5; H, 4.9; N, 8.3\%. MS ESI $(\mathrm{m} / \mathrm{z}): 381\left[\mathrm{MnL}^{1}\right]^{+}, 824\left[\mathrm{Mn}_{2} \mathrm{~L}_{2}{ }_{2}\left(\mathrm{NO}_{3}\right)\right]^{+}$. IR $\left(\mathrm{KBr}, \mathrm{cm}^{-1}\right): v(\mathrm{O}-\mathrm{H}) 3420(\mathrm{~m}), v(\mathrm{C}=\mathrm{N})$ 1619 (vs), $v(\mathrm{C}-\mathrm{O}) 1257$ (s), v(NO 3$) 1384$ (vs), 830 (m), 738 (s). ${ }^{1} \mathrm{H}$ NMR (DMSO-d 6 , ppm): $\delta-30.52$ (H4), -21.50 (H5). $\mu=5.1$ BM. $\Lambda_{M}=81 \mu \mathrm{S}$.

$\mathbf{M n}_{2} \mathbf{L}^{2}{ }_{2}\left(\mathbf{H}_{2} \mathbf{O}\right)_{2}(\mathbf{D C A})_{2}(4), 0.46 \mathrm{mmol}(0.15 \mathrm{~g})$ of $\mathrm{H}_{2} \mathrm{~L}^{2}$ was dissolved in methanol (40 mL) and $0.46 \mathrm{mmol}(0.11 \mathrm{~g})$ of $\mathrm{Mn}\left(\mathrm{CH}_{3} \mathrm{COO}\right)_{2}$ was added to the initial yellow solution which changed to brown. The mixture was gently heated and stirred for $30 \mathrm{~min}$, and then $0.46 \mathrm{mmol}(0.04 \mathrm{~g})$ of $\mathrm{NaN}(\mathrm{CN})_{2}$ in $10 \mathrm{~mL}$ of methanol was added. Anal. Calcd. for $\mathrm{C}_{40} \mathrm{H}_{40} \mathrm{Mn}_{2} \mathrm{~N}_{10} \mathrm{O}_{10}$ (930.8): C, 51.6; $\mathrm{H}$, 4.3; N, 15.0. Found: C, 50.8; H, 4.4; N, $14.8 \%$. MS ES $(\mathrm{m} / \mathrm{z}): 381[\mathrm{MnL}]^{+} ; 828[\mathrm{MnL}(\mathrm{DCA})]^{+}$. IR $\left(\mathrm{KBr}, \mathrm{cm}^{-1}\right): v(\mathrm{O}-\mathrm{H}) 3421(\mathrm{~m}), v(\mathrm{C}=\mathrm{N}) 1624(\mathrm{vs}), v(\mathrm{C}-\mathrm{O}) 1259(\mathrm{~s}), v_{\mathrm{sym}}(\mathrm{C} \equiv \mathrm{N}) 2148(\mathrm{vs}), v_{\text {asym }}(\mathrm{C} \equiv \mathrm{N})$ $2266(\mathrm{~m}) . \mu=5.0 \mathrm{BM}$. Conductivity (in $\mathrm{MeOH}) \Lambda_{M}=33 \mu \mathrm{S}$.

$\mathrm{MnL}^{3}\left(\mathrm{H}_{2} \mathrm{O}\right)_{2}\left(\mathbf{C l O}_{4}\right)(5)$, Synthetic procedure similar to $\mathbf{1}$, using $2.00 \mathrm{mmol}(1.0 \mathrm{~g})$ of $\mathrm{H}_{2} \mathrm{~L}^{3}$, $2.00 \mathrm{mmol}(0.72 \mathrm{~g})$ of $\mathrm{Mn}\left(\mathrm{ClO}_{4}\right)_{2} \cdot 6 \mathrm{H}_{2} \mathrm{O}$ and $4.00 \mathrm{mmol}(0.16 \mathrm{~g})$ of $\mathrm{NaOH}$. Anal. Calcd. for $\mathrm{C}_{19} \mathrm{H}_{22} \mathrm{Br}_{2} \mathrm{ClMnN}_{2} \mathrm{O}_{10}$ (688.2): C, 33.1; H, 3.2; N, 4.1. Found: C, 33.5; H, 3.2; N, $4.0 \%$. MS ES (m/z): 
$554[\mathrm{MnL}]^{+}$. IR $\left(\mathrm{KBr}, \mathrm{cm}^{-1}\right): v(\mathrm{O}-\mathrm{H}) 3431(\mathrm{~m}), v(\mathrm{C}=\mathrm{N}) 1624(\mathrm{vs}), v(\mathrm{C}-\mathrm{O}) 1294(\mathrm{~s}), v_{3}\left(\mathrm{ClO}_{4}{ }^{-}\right)$ 1119 (vs). $\mu=4.6 \mathrm{BM}$. Conductivity (in DMF) $\Lambda_{M}=115 \mu \mathrm{S}$.

$\mathrm{MnL}^{4}\left(\mathrm{H}_{2} \mathbf{O}\right)_{2}\left(\mathbf{N O}_{3}\right)\left(\mathbf{H}_{2} \mathbf{O}\right)_{3},(6)$. Synthetic procedure similar to 3, using $0.68 \mathrm{mmol}(0.25 \mathrm{~g})$ of $_{2} \mathrm{~L}^{4}$, and $0.68 \mathrm{mmol}(0.18 \mathrm{~g})$ of $\mathrm{Mn}\left(\mathrm{NO}_{3}\right)_{2} .4 \mathrm{H}_{2} \mathrm{O}$. Anal. Calcd. for $\mathrm{C}_{21} \mathrm{H}_{32} \mathrm{MnN}_{3} \mathrm{O}_{11}$ (557.4): C, 45.2; H, 5.8; $\mathrm{N}$, 7.5. Found: C, 45.3; H, 5.7; N, 7.5\%. MS ESI $(\mathrm{m} / z): 423\left[\mathrm{MnL}^{5}\right]^{+}, 908\left[\mathrm{Mn}_{2} \mathrm{~L}_{2}{ }_{2}\left(\mathrm{NO}_{3}\right)\right]^{+}$. IR $(\mathrm{KBr}$, $\left.\mathrm{cm}^{-1}\right): v(\mathrm{O}-\mathrm{H}) 3427(\mathrm{~m}), v(\mathrm{C}=\mathrm{N}) 1609(\mathrm{vs}), v(\mathrm{C}-\mathrm{O}) 1254(\mathrm{~s}), v\left(\mathrm{NO}_{3}\right) 1384(\mathrm{vs}), 850(\mathrm{~m}), 739$ (s). ${ }^{1} \mathrm{H}$ NMR (DMSO-d 6 , ppm): $\delta-21.97$ (H4), $-18.00(\mathrm{H} 5) . \mu=5.3$ BM. $\Lambda_{M}=68 \mu \mathrm{S}$.

\subsection{X-ray Diffraction Studies}

Single crystals of Complex 4 suitable for X-ray diffraction studies were obtained by slow evaporation of the methanolic solution at room temperature. Detailed crystal data collection and refinement are summarized in Table 3. The structures were solved by direct methods [35] and finally refined by full-matrix least-squares base on $F^{2}$. An empirical absorption correction was applied using SADABS [36]. All non-hydrogen atoms were included in the model at geometrically calculated positions.

The Cambridge crystallographic data centre (CCDC) reference number 916337 contains the supplementary crystallographic data for 4. These data can be obtained free of charge at www.cdcc.cam.ac.uk/conts/retrieving.html (or from the Cambridge Crystallographic Data Centre, 12 Union Road, Cambridge CB2 1EZ, UK [Fax: + 44-1223/336-033; E-Mail: deposit@ccdc.cam.ac.uk].

Table 3. Crystal data and structure refinement for 4.

\begin{tabular}{|c|c|}
\hline Empirical formula & $\mathrm{C}_{20} \mathrm{H}_{20} \mathrm{MnN}_{5} \mathrm{O}_{5}$ \\
\hline Formula weight & 465.35 \\
\hline Temperature $[\mathrm{K}]$ & $100(2)$ \\
\hline Wavelength $[\AA]$ & 0.71073 \\
\hline Crystal system & Monoclinic \\
\hline Space group & $\mathrm{P} 2{ }_{1} / \mathrm{c}$ \\
\hline$a[\AA]$ & $11.3350(4)$ \\
\hline$b[\AA]$ & $21.7336(9)$ \\
\hline$c[\AA]$ & $8.5965(3)$ \\
\hline$\alpha\left[^{\circ}\right]$ & 90 \\
\hline$\beta\left[{ }^{\circ}\right]$ & $108.591(2)$ \\
\hline$\gamma\left[^{\circ}\right]$ & 90 \\
\hline Volume $\left[\AA^{3}\right]$ & $2007.24(13)$ \\
\hline $\mathrm{Z}$ & 4 \\
\hline $\mathrm{D}_{\text {calcd. }}\left[\mathrm{g} \mathrm{cm}^{-3}\right]$ & 1.540 \\
\hline$\mu\left[\mathrm{mm}^{-1}\right]$ & 0.702 \\
\hline $\mathrm{F}(000)$ & 960 \\
\hline$\theta_{\min / \max }\left[{ }^{\circ}\right]$ & $1.87 / 27.88$ \\
\hline Total data & 28313 \\
\hline Unique data & 4792 \\
\hline Final $R$ indices $[I>2 \sigma(\mathrm{I})]$ & $R_{1}=0.0417 ; w R_{2}=0.1109$ \\
\hline $\mathrm{R}$ indices (all data) & $R_{1}=0.0494 ; w R_{2}=0.1163$ \\
\hline
\end{tabular}




\subsection{Peroxidase Probes}

Oxidation of ABTS with $\mathrm{H}_{2} \mathrm{O}_{2}$ at $c a$. pH 7 in the presence of the complexes was tested in the following manner. An aqueous solution of ABTS (50 $\left.\mu \mathrm{L} ; 0.009 \mathrm{M} ; 4.5 \times 10^{-7} \mathrm{~mol}\right)$ and a methanolic solution of the complex $\left(10 \mu \mathrm{L} ; 10^{-3} \mathrm{M} ; 10^{-8} \mathrm{~mol}\right)$ were added to water $(3 \mathrm{~mL})$. The intensity of the UV absorption bands of ABTS started to increase immediately after addition of an aqueous solution of $\mathrm{H}_{2} \mathrm{O}_{2}\left(50 \mu \mathrm{L} ; 10 \mathrm{M} ; 5 \times 10^{-4} \mathrm{~mol}\right)$. The disproportionation of hydrogen peroxide by the Complexes 1-6 (catalase activity) was not observed for the concentrations of this peroxidase assay.

\subsection{Oxidation of Veratryl Alcohol}

Veratryl alcohol (200 mmol, $0.29 \mathrm{~mL})$, previously dissolved in $20 \mathrm{~mL}$ of dihydrogenphosphate/ $\mathrm{NaOH}$ buffer $\mathrm{pH}$, was mixed with a methanolic solution $(15 \mathrm{~mL})$ of the catalytic complex $(0.5 \mathrm{mmol}, \mathrm{ca} .6 \mathrm{mg})$. The oxidant $(600 \mathrm{mmol})$ was added in three portions at 20 min intervals. The reaction mixture was stirred for 10 hours at $22{ }^{\circ} \mathrm{C}$ with an air flow bubbling through the solution and then filtered through a short silica gel plug to remove the catalyst and excess oxidant. The reaction mixture was extracted in $\mathrm{CH}_{2} \mathrm{Cl}_{2}$ in the presence of saturated aqueous $\mathrm{NaCl}$ solution. The organic layer was dried over $\mathrm{MgSO}_{4}$ and evaporated under reduced pressure. The mixture was then purified by column chromatography using a 1:1 mixture of ethyl acetate:hexane as eluent. The veratraldehyde fraction was characterized by NMR spectrometry. ${ }^{1} \mathrm{H}$ NMR (300 MHz) for the veratraldehyde fraction: $9.62(\mathrm{~s}, 1 \mathrm{H}) ; 7.44(\mathrm{~d}, 1 \mathrm{H}) ; 7.33(\mathrm{~s}, 1 \mathrm{H}) ; 7.18(\mathrm{~d}, 1 \mathrm{H}) ; 3.83(\mathrm{~s}, 6 \mathrm{H})$; ${ }^{1} \mathrm{H}$ NMR (300 MHz) for original commercial veratryl alcohol: $7.03(\mathrm{~s}, 1 \mathrm{H}) ; 6.81(\mathrm{~d}, 1 \mathrm{H}) ; 6.55(\mathrm{~d}, 1 \mathrm{H})$; $4.61(\mathrm{~s}, 2 \mathrm{H}) ; 3.83(\mathrm{~s}, 6 \mathrm{H})$.

\section{Conclusions}

This work again further emphasizes the suitability of Schiff bases with inner and outer O-R ( $\mathrm{R}=\mathrm{CH}_{3}$ in the present work) groups for establishing rich hydrogen-bonding networks. The X-ray structure of 4 shows the self-assembly of the Mn(III)-Schiff base complexes through $\mu$-aquo bridges. This type of structure is crucial to obtain peroxidase-like activity for these complexes. 1-4 behave as efficient peroxidase mimics achieving TON close to 300 catalytic cycles. The four complexes are also able to decompose veratryl alcohol, a lignin analogue, with relevant yields in very mild conditions.

\section{Acknowledgments}

We thank Xunta de Galicia (09DPI004291PR) for financial support. We also thank Juan C. García-Monteagudo for the use of his potentiostat and for his invaluable help with electrochemical measurements. The authors especially thank the reviewers of the manuscript for their helpful suggestions.

\section{Conflict of Interest}

The authors declare no conflict of interest. 


\section{References}

1. Sixta, H.; Potthast, A.; Krotschek, A.W. Chemical pulping processes. In Handbook of Pulp; Sixta, H., Ed.; Wiley-VCH: Winheim, Germany, 2006.

2. Isroi, I.; Millati, R.; Syamsiah, S.; Niklasson, C.; Cahyanto, M.N.; Lundquist, K.; Taherezadeh, M.J. Biological pretreatment of lignocelluloses with white-rot fungi and its applications: a review. Bioresources 2011, 6, 5224-5259.

3. Pokhrel, D.; Viraraghavan, T. Treatment of pulp and paper mill wastewater - a review. Sci. Total Environ. 2004, 333, 37-58.

4. Muñoz, I.; Rieradevall, J.; Torrades, F.; Peral, J.; Domènech, X. Environmental assessment of different advanced oxidation processes applied to a bleaching Kraft mill effluent. Chemosphere 2006, 62, 9-16.

5. Bajpai, P. Biological bleaching of chemical pulps. Crit. Rev. Biotechnol. 2004, 24, 1-58.

6. Galliano, H.; Gas, G.; Seris, J.L.; Boudet, A.M. Lignin degradation by rigidoporus-lignosus involves synergistic action of 2-oxidizing enzymes- Mn peroxidase and laccase. Enzyme Microb. Technol. 1991, 13, 478-482.

7. Hage, R.; Lienke, A. Applications of transition-metal catalysts to textile and wood-pulp bleaching. Angew. Chem. Int. Ed. 2006, 45, 206-222.

8. Chen, C.-L.; Capanema, E.A.; Gracz, H.S. Reaction mechanisms in delignification of pine Kraft-AQ pulp with hydrogen peroxide using Mn(IV)-Me ${ }_{4} \mathrm{DTNE}$ as catalyst. J. Agric. Food Chem. 2003, 51, 1932-1941.

9. Biava, H.; Signorella, S. Peroxidase activity of dimanganese(III) complexes with the $\left[\operatorname{Mn}_{2}(\mu-\right.$ OAc) $\left.(\mu-\mathrm{OR})_{2}\right]^{3+}$ core. Polyhedron 2010, 29, 1001-1006.

10. Dolphin, D.; Traylor, T.G.; Xie, L.Y. Polyhaloporphyrins: Unusual ligands for metals and metalcatalyzed oxidations. Acc. Chem. Res. 1997, 30, 251-259.

11. Crestini, C.; Pastorini, A.; Tagliatesta, P. Metalloporphyrins immobilized on motmorillonite as biomimetic catalysts in the oxidation of lignin model compounds. J. Mol. Catal. A 2004, 208, 195-202.

12. Bermejo, M.R.; Fernández, M.I.; Gómez-Fórneas, E.; González-Noya, A.; Maneiro, M.; Pedrido, R.; Rodríguez, M.J. Self-assembly of dimeric Mn(III)-Schiff-base complexes tuned by perchlorate anions. Eur. J. Inorg. Chem. 2007, 2007, 3789-3797.

13. Vázquez-Fernández, M.A.; Bermejo, M.R.; Fernández-García, M.I.; González-Riopedre, G.; Rodríguez-Doutón, M.J.; Maneiro, M. Influence of the geometry around the manganese ion on the peroxidase and catalase activities of $\mathrm{Mn}(\mathrm{III})-\mathrm{Schiff}$ base complexes. J. Inorg. Biochem. 2011, $105,1538-1547$.

14. Maneiro, M.; Bermejo, M.R.; Fernández, M.I.; Gómez-Fórneas, E.; González-Noya, A.M.; Tyryshkin, A.M. A new type of manganese-Schiff base complex, catalysts for the disproportionation of hydrogen peroxide as peroxidase mimics. New J. Chem. 2003, 27, 727-733.

15. Bermejo, M.R.; Fernández, M.I.; González-Noya, A.M.; Maneiro, M.; Pedrido, R.; Rodríguez, M.J.; García-Monteagudo, J.C.; Donnadieu, D. Novel peroxidase mimics: $\mu$-Aqua manganeseSchiff base dimers. J. Inorg. Biochem. 2006, 100, 1470-1478. 
16. Zucca, P.; Sollai, F.; Garau, A.; Rescigno, A.; Sanjust, E. Fe(III)-5,10,15,20tetrakis(pentafluorophenyl)porphine supported on pyridyl-functionalized, crossliked poly(vinyl alcohol) as biomimetic versatile-peroxidase-like catalyst. J. Mol. Catal. A 2009, 306, 89-96.

17. Bermejo, M.R.; Fondo, M.; Garcia-Deibe, A.; González-Noya, A.M.; Sousa, A.; Sanmartín, J.; McAuliffe, C.A.; Pritchard, R.G.; Watkinson, M.; Lukov, V. Studies of the binding modes of carboxylate donors with manganese(III) complexes containing tetradentate Schiff base ligands. Crystal structures of the complexes $\left[\mathrm{Mn}\left(3-\mathrm{CH}_{3} \mathrm{Osalpn}\right)\left(\mathrm{HO}_{2} \mathrm{CC}_{6} \mathrm{H}_{4} \mathrm{CO}_{2}\right)\right]_{n}$ and $\left[\left\{\mathrm{Mn}\left(5-\mathrm{NO}_{2} \mathrm{Salpn}\right)(\mathrm{OH})\left(\mathrm{H}_{2} \mathrm{O}\right)\right\} \quad\left[\left\{\mathrm{Mn}\left(5-\mathrm{NO}_{2} \mathrm{Salpn}\right)\left(\mathrm{HO}_{2} \mathrm{CC}_{6} \mathrm{H}_{4} \mathrm{CO}_{2}\right)\left(\mathrm{H}_{2} \mathrm{O}\right)\right\} \cdot \mathrm{C}_{2} \mathrm{H}_{5} \mathrm{OH}\right.\right.$. Inorg. Chim. Acta 1999, 293, 210-217.

18. Kong, D.; Xie, Y. Synthesis, structural characterization of tetraazamacrocyclic ligand, fivecoordinated zinc(II). Inorg. Chim. Acta 2002, 338, 142-148.

19. Majumder, A.; Pilet, G.; Garland, M.T.; Mitra, S. Synthesis and structural characterisation of three dicyanamide complexes with $\mathrm{Mn}(\mathrm{II}), \mathrm{Zn}(\mathrm{II})$ and $\mathrm{Cd}(\mathrm{II})$ : Supramolecular architectures stabilised by hydrogen bonding. Polyhedron 2006, 25, 2550-2558.

20. Constable, E.C.; Housecroft, C.E.; Kopecky, P.; Schonhofer, E.; Zampese, J.A. Restricting the geometrical relaxation in four-coordinate copper(I) complexes using face-to-face and edge-to-face $\pi$-interactions. CrystEngComm 2011, 13, 2742-2752.

21. Eulering, B.; Schmidt, M.; Pinkernell, V.; Karst, U.; Krebs, B. An unsymmetrical dinuclear iron(III) complex with peroxidase properties. Angew. Chem. Int. Ed. 1996, 35, 1973-1974 (in English).

22. Cozzi, P.G. Metal-Salen Schiff base complexes in catalysis: practical aspects. Chem. Soc. Rev. 2004, 33, 410-421.

23. Hage, R.; Lienke, A. Bleach and oxidation catalysis by manganese-1,4,7-triazacyclononane complexes and hydrogen peroxide. J. Mol. Catal. A 2006, 251, 150-158.

24. Signorella, S.; Hureau, C. Bioinspired functional mimics of the manganese catalases. Coord. Chem. Rev. 2012, 256, 1229-1245.

25. Oliveri, V.; Puglisi, A.; Vecchio, G. New conjugates of $\beta$-cyclodextrin with manganese(III) salophen and porphyrin complexes as antioxidant systems. Dalton Trans. 2011, 40, 2913-2919.

26. González-Riopedre, G.; Fernández-García, M.I.; González-Noya, A.M.; Vázquez-Fernández, M.; Bermejo, M.R.; Maneiro, M. Manganese-Schiff base complexes as catalysts for water photolysis. Phys. Chem. Chem. Phys. 2011, 13, 18069-18077.

27. Kervinen, K.; Lahtinen, P.; Repo, T.; Svanh, M.; Leskela, M. The effect of reaction conditions on the oxidation of veratryl alcohol catalyzed by cobalt salen-complexes. Catal. Today 2002, 75, 183-188.

28. Liu, A.; Huang, X.; Song, S.; Wang, D.; Xuemei, L.; Qu, Y.; Gao, P. Kinetics of the $\mathrm{H}_{2} \mathrm{O}_{2^{-}}$ dependent ligninase-catalyzed oxidation of veratryl alcohol in the presence of cationic surfactant studied by spectrophotometric technique. Spectrochim. Acta Part A 2003, 59, 2547-2551.

29. Simandi, L. Advances in Catalytic Activation of Dioxygen by Metal Complexes; Kluwer Academic Publishers: Dordrecht, The Netherlands, 2003.

30. Korpi, H.; Sippola, V.; Filpponen, I.; Sipilä, J.; Krausse, O.; Leskeläm, M.; Repo, R. Copper-2,2'bipyridines: Catalytic performance and structures in aqueous alkaline solutions. Appl. Catal. A 2006, 302, 250-256. 
31. Zakzeski, J.; Jongerius, A.L.; Weckhuysen, B.M. Transition metal catalyzed oxidation of Alcell lignin, soda lignin, and lignin model compounds in ionic liquids. Green Chem. 2010, 12, 1225-1236.

32. Crestini, C.; Pastorini, A.; Tagliatesta, P. The immobilized porphyrin-mediaton system $\mathrm{Mn}(\mathrm{TMePyP}) /$ clay/HBT (clay-PMS): A Lignin peroxidase biomimetic catalyst in the oxidation of lignin and lignin model compounds. Eur. J. Inorg. Chem. 2004, 4477-4483.

33. Cui, F.; Dolphin, D. Iron porphyrin catalyzed oxidation of lignin model compounds: the oxidation of veratryl alcohol and veratryl acetate. Can. J. Chem. 1992, 70, 2314-2318.

34. Sippola, V.O.; Krause, A.O.I. Bis( $O$-phenanthroline)copper-catalysed oxidation of lignin model compounds for oxygen bleaching of pulp. Catal. Today 2005, 100, 237-242.

35. Sheldrick, G.M. SHELX-97 (shelxs 97 and shelx1 97), Programs for Crystal Structure Analyses, version 97-1; University of Göttingen: Göttingen, Germany, 1997.

36. Sheldrick, G.M. SADABS (Program for Scaling and Correction of Area Detector Data), version 2008/1; University of Göttingen: Göttingen, Germany, 2008.

(C) 2013 by the authors; licensee MDPI, Basel, Switzerland. This article is an open access article distributed under the terms and conditions of the Creative Commons Attribution license (http://creativecommons.org/licenses/by/3.0/). 